\title{
A LEPROSY SURVEY IN ZANZIBAR AND PEMBA
}

JAMES ROSS INNES.

INTRODUCTION.

Between the dates I6th July and I6th August I95I, the author was loaned by the East African High Commission to the Zanzibar Government for a leprosy survey of Zanzibar and Pemba. With the generous and assiduous assistance of all members of the administrative and medical departments of His Highness's Government, it was found possible to complete an adequate survey in both islands, by examining samples of the populations in a great number of places. There was not a corner of the country into which the survey team did not penetrate, and the team included Mr. L. G. W. Vear, a leprosy worker from the British Empire Leprosy Relief Association.

In deference to local sentiment, it was found necessary in Zanzibar island to omit the examination of females, but in Pemba Island adequate numbers of females also volunteered for examination. 
The island of Zanzibar has a land area of 640 square miles and a population of 150,000 , whilst Pemba has a land area of 380 square miles, and a population of II4,000. Both lie close to the coast of East Africa, and latitude $5 \mathrm{~S}$. passes through Pemba, and latitude $6 \mathrm{~S}$. through Zanzibar. Both have a long history, and in modern times comprise a Sultanate and Protectorate with a British Resident. The islands are noted for their clove top crops, coconuts, and similar products. The climate is warm and humid.

In effecting the survey, it was found necessary to travel by ship, motor car, launch, dhow, canoe, and on foot. Zanzibar was covered in 12 working days, Pemba in I3. Certain of the Tumbatu people in Zanzibar refused co-operation with the survey, but most people co-operated splendidly, particularly in Pemba, where a total of 2I,903 people were obtained for examination. In Zanzibar, the total was 10,786 . The leprosy rate emerged as very moderate in both islands. Already in existence are two small leprosaria, of about 50 inpatients, one at Walezo in Zanzibar, the other at Makondeni in Pemba.

\section{Section A. Results of Leprosy Survey in Zanzibar.}

\begin{tabular}{|c|c|c|c|c|c|c|}
\hline Hate & Places & $\begin{array}{l}\text { Male } \\
\text { pop. at } \\
\text { risk }\end{array}$ & $\begin{array}{l}\text { No. of } \\
\text { males } \\
\text { examined }\end{array}$ & $\begin{array}{l}\text { No. of } \\
\text { cases of } \\
\text { leprosy }\end{array}$ & $\begin{array}{c}\text { Crude } \\
\text { rate per } \\
1,000\end{array}$ & $\begin{array}{c}\text { Corrected } \\
\text { rate } \\
\text { per } 1,000\end{array}$ \\
\hline I7 July & Zanzibar City $\quad \ldots$ & 20,000 & 2,000 & 4 & 2.0 & I. 5 \\
\hline $\begin{array}{l}18 \quad, \\
19 \quad,\end{array}$ & $\begin{array}{l}\text { Mwole, Bububu, } \\
\text { Fuoni, Uzini, } \\
\text { Kidimni, Ndagaa, }\end{array}$ & 4,000 & 637 & 2 & 2.9 & 2.17 \\
\hline $20 \quad$, & $\begin{array}{l}\text { Mchangani ... } \\
\text { Mkamburimsafa, } \\
\text { Mwera, Ndijani, }\end{array}$ & 5,000 & I,006 & 7 & 6.9 & 5.17 \\
\hline 2 I $\underset{\text { July }}{\& 22}$ & $\begin{array}{l}\text { Chwaka, Uroa } \\
\text { Bungi, Kikungwi, } \\
\text { Unguja, Ukuu, Pete, } \\
\text { Kitogani, Jambiani, } \\
\text { Paje, Bwejuu, Prison } \\
\text { Farms }\end{array}$ & 3,000 & 924 & 3 & 3.2 & 2.4 \\
\hline & $\begin{array}{l}\text { Farms } \\
\text { Muyuni, Kizimkazi, } \\
\text { Kibutani, Mtende, }\end{array}$ & 6,000 & I, I I 8 & 2 & I. 7 & I. 27 \\
\hline 24, & $\begin{array}{l}\text { Makunduchi } \\
\text { Mfenesini, Mekundu, } \\
\text { Fujoni, Mangapwani, }\end{array}$ & 7,000 & $85 \mathrm{I}$ & 4 & $4 \cdot 7$ & $3 \cdot 5 \mathrm{I}$ \\
\hline 25 July & $\begin{array}{l}\text { Misufini, Makoba ... } \\
\text { Kazole, Mahonda, } \\
\text { Mbiji, Donge, Mko- } \\
\text { kotoni, Mkwajuni. }\end{array}$ & 4,000 & 686 & 5 & 7.2 & $5 \cdot 4$ \\
\hline $26 \quad$, & $\begin{array}{l}\text { kotonı, Mkwajunı. } \\
\text { Tumbatu I. }\end{array}$ & $\begin{array}{l}5,000 \\
1,500\end{array}$ & $\begin{array}{r}I, 536 \\
71\end{array}$ & 9 & $\stackrel{5.8}{-}$ & $4 \cdot 3$ \\
\hline $27,$. & $\begin{array}{l}\text { Kinduni, Mgambo, } \\
\text { Kinyasini, Upenja, } \\
\text { Chaani, Chutampa, } \\
\text { Moga } \\
\text { Potowa, Kidoto, ... }\end{array}$ & 5,000 & $\mathrm{I}, 78 \mathrm{I}$ & 9 & 5.0 & 3.8 \\
\hline & Kigunda, Nungwi .. & 4,000 & 138 & 2 & - & - \\
\hline & Grand totals & & 10.748 & 47 & $4 \cdot 3$ & 3.9 \\
\hline
\end{tabular}


NOTES.

The correction for lack of females is based on the assumption that two males to every female contract leprosy.

For Zanzibar the average leprosy rate per thousand population may thus be taken as 3.9 per 1000 , and the estimated total number of leprosy cases existing as 600 .

\section{Section B. Results of Leprosy Survey in Pemba.}

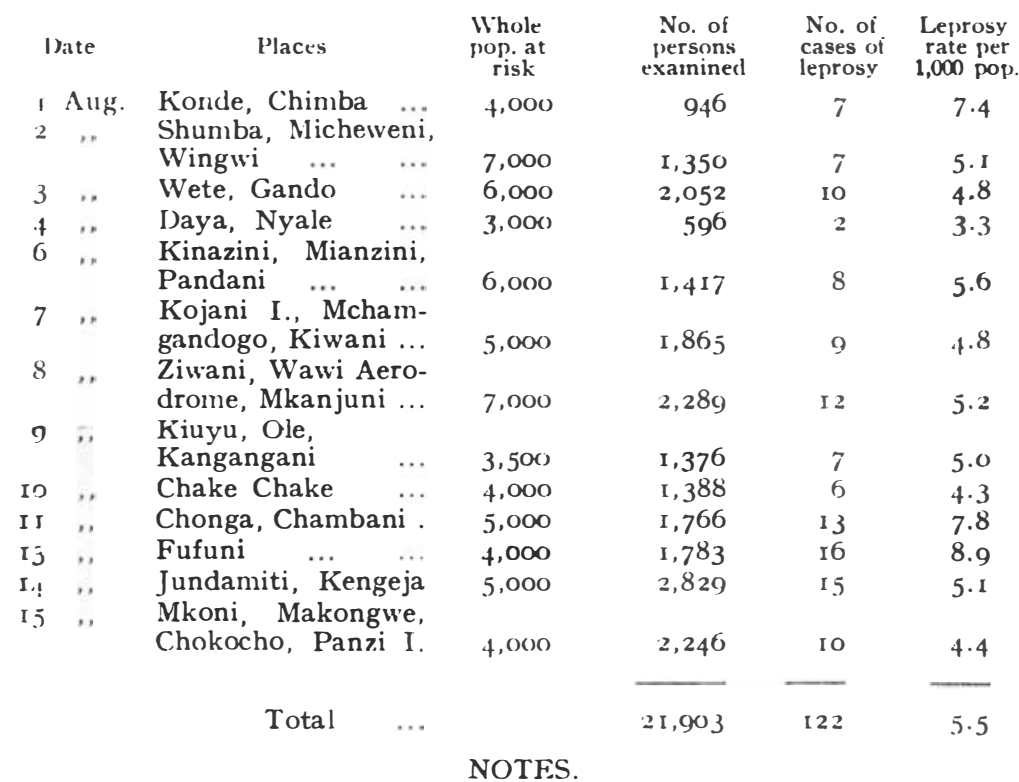

As an adequate representation of females as well as males was obtained in Pemba, the leprosy rate per 1000 may bc taken as 5.5. The estimated number of cases of leprosy existing in Pemba is 600 .

Section C. Analysis of the Cases of Leprosy found. 169 Cases.

(I) Sex. The 47 cases in Zanzibar were all males, as only males offered for the survey. Of the I22 Pemba cases, 45 were females.

(2) Age incidence. (a) Children. The number of cases of age I4 years and under were 37 , or 21.8 per cent. of the whole. ages I4 I3 I2 II IO 8776

number $\begin{array}{lllllllll}2 & 2 & 6 & 7 & 4 & 5 & 6 & 5\end{array}$

(b) adults, or those over I4 years, were I32 cases

$\begin{array}{lcccccccccccc}\text { ages } & 60 & 55 & 50 & 45 & 40 & 35 & 30 & 25 & 20 & \text { I8 } & \text { I6 } & \text { I5 } \\ \text { number } & 4 & 3 & \text { II } & \text { I3 } & \text { I6 } & \text { I7 } & 29 & \text { 2I } & \text { I2 } & 2 & \text { I } & 3\end{array}$ 
(3) Racial or tribal origins. The race or tribe, as given by the patient or his relatives, was in the I69 cases as follows:-

\begin{tabular}{|c|c|c|c|}
\hline irazi & $\cdots$ & 64 & cases \\
\hline Arab & $\ldots$ & 28 & ,. \\
\hline Tumbatu & $\ldots$ & 19 & ,. \\
\hline Swahili & & 15 & ,. \\
\hline Wahadimu & $\ldots$ & 6 & \\
\hline Wanyamwezi & & 8 & ., \\
\hline Kojani & & 5 & ", \\
\hline Yao & $\ldots$ & 4 & ,. \\
\hline Kikuyu & $\ldots$ & 3 & .. \\
\hline Ndingo & $\ldots$ & 3 & .. \\
\hline Makonde & $\ldots$ & 2 & .. \\
\hline Kadum & & 2 & ,, \\
\hline Mzeramu & $\ldots$ & & \\
\hline Nyasa ... & & & \\
\hline
\end{tabular}

It was interesting to find that there were I4 cases of leprosy who derived from Central or East African mainland tribes, and had been born in Zanzibar and Pemba.

Also strangers from the mainland, some i6 cases of leprosy, had the following varying degrees of residence:-

\begin{tabular}{|c|c|c|c|c|c|c|c|}
\hline 37 years & $\cdots$ & I case & 2 & years & $\ldots$ & I & case \\
\hline 30 years & $\ldots$ & + cases & 6 & months & $\ldots$ & t & .. \\
\hline 20 years & $\ldots$ & 2 & 5 & months & $\ldots$ & I & .. \\
\hline ro years & $\ldots$ & , & 2 & months & & 1 & .. \\
\hline 8 years & $\ldots$ & I case & 1 & month & $\ldots$ & I & ., \\
\hline \& years & $\ldots$ & 1 & & & & & \\
\hline
\end{tabular}

We see in this reflection of the probable source of most of the leprosy of these islands in the past and present, namely the importation of slaves in the past, and paid labour today, from the African mainland. About 18 per cent. of all cases of leprosy found were of mainland origin.

(4) Living Conditions. Of these cases, 28 or I6 per cent. lived alone, but 82 lived in house contact with a total of 252 children. In all cases, housing was inadequate in light and air entry, and overcrowded. The custom of multiple wives was observed in the case of 7 men, who had three wives to two wives apiece. The percentage living alone is much higher than has been observed in surveys on the mainland, where it is usually about 5 per cent. who live alone, so some greater degree of the understanding of the need for isolation, is evident. The child cases in contact point, as ever, to the way leprosy is perpetuated in the community.

Groups of family leprosy, that is, one or more members of the same family afflicted with leprosy, were observed in Io distinct instances. The original source of the infection in the family was usually a parent or elder relative.

(5) Clinical type of leprosy.

Lepromatous leprosy, the infectious type, was found in 32 cases. or I8. per cent. 
There was a great predominance of elevated tuberculoid lesions of leprosy, these cases numbering io3, or 60 per cent.

Intermediate and polyneuritic cases were of lesser importance.

\section{Si:ction D. The Leprosy Problem in Zanzibar and Pemba.}

The position is that we must expect to deal with some 600 cases of leprosy in each island. This is a moderate problem, contrasting with the East African countries of Tanganyika, Kenya, and Uganda, where, as my previous surveys have shown, we have to deal with 215,000 cases.

Already in existence are the two small leprosaria of Walezo and Makondeni, where about 50 cases each are in residence. Of these leprosaria, the use of the sulphone drugs was introduced in Walezo after my visit in February, I95I, and at Makondeni, their use is just being started. Both these leprosaria are controlled by visiting physicians, and resident staff comprises a Catholic sisterhood at Walezo, and a health department assistant at Makondeni.

In small islands like these, there is much more prospect of an attempt at complete control of leprosy being effective within a reasonable time, if the mechanism of control is enhanced and improved. To go on with the present mechanism, even with the use added of the sulphone drugs, success will not be assured. True success will follow when a control officer is appointed for each island, who will gain the confidence of the people, and ensure that each case is found and encouraged to come in. A considerable proportion of the cases are of the moderate type, and readily brought to the stage of arrest of the disease. I do not recommend that cases should be treated at home or by dispensary medication. In such small countries, it is practical and safer to insist on institutional treatment in all cases, whether infectious, or the little infectious tuberculoid and indeterminate cases. Admitted cases have the advantage of the more steady clinical observation and the use of laboratory aids such as the lepromin test and blood examinations, all of which aid success. It is important also that cases should be encouraged, if their clinical state permits, to engage in open-air work, which definitely helps in cure. In domicilary cases, such work is hard to ensure.

The outline of a plan which I consider will meet the leprosy problem in Zanzibar and Pemba is as follows:-

(I) The sulphone drugs should be stocked in adequate amount and provided free by Government. Ancillary drugs should also be provided.

(2) The existing leprosaria should be enlarged to be able to 
contain a total of I50 patients. New patients' houses should be built, and extra African staff attached. Enough agricultural land should be provided to give all patients ample cultivation work, and light industries of the carpentry type provided for. Medical control should be arranged for on the daily attendance basis.

(3) The help of the British Empire Leprosy Relief Association should be sought to provide a BELRA lay worker for each island, the duties of whom would be to help the leprosarium in every way possible, and above all to tour constantly and get to know the island and the people, to gain the confidence of the people, and to arrange the treatment of cases of leprosy, and conduct future survey work.

(4) A bouse to be provided by the Zanzibar Government in a convenient spot near to each leprosarium. This may mean building a new house near Makondeni in Pemba, but in Zanzibar an existing house may be found. One, two, or three miles distance from the leprosarium is suitable.

(5) The provision by the Zanzibar Government of a motor vebicle and running costs of same to each BELRA worker.

(6) The spread of the information also through District Commissioners and Mudirs amongst the people that modern treatment and care for leprosy sufferers are now to be provided, and that they will be welcomed if they come forward. If accommodation is not immediately available, advice on modified home segregation and the benefits of separation from child contacts can be disseminated, not only by the BELRA workers, but by all administrative officers and influential numbers of the community.

(7) The resistance of the Tumbatu people to the leprosy survey in certain places might suggest that a hard core of non-co-operation might spoil the ultimate success of the plan of leprosy control. I suggest that if good work is done for those who do come, the ultimate attitude of any possible objectors will be changed to a wish to share in the benefits available, for their people and themselves.

(8) The infiltration of foreign leprosy cases needs to be thought of. Some accepted method of inspection of African labour for leprosy must be set up. Every country has the right to inspect visitors and immigrants for leprosy. The chief difficulty is the control of all the coasts for landings from dhows. When public opinion grows, later it might be possible to introduce some plan of inspection. The position as regards these islands is that leprosy exists and owes its origin to imported leprosy in the past. The seasonal importation of labour remains still a potential source of new cases. 


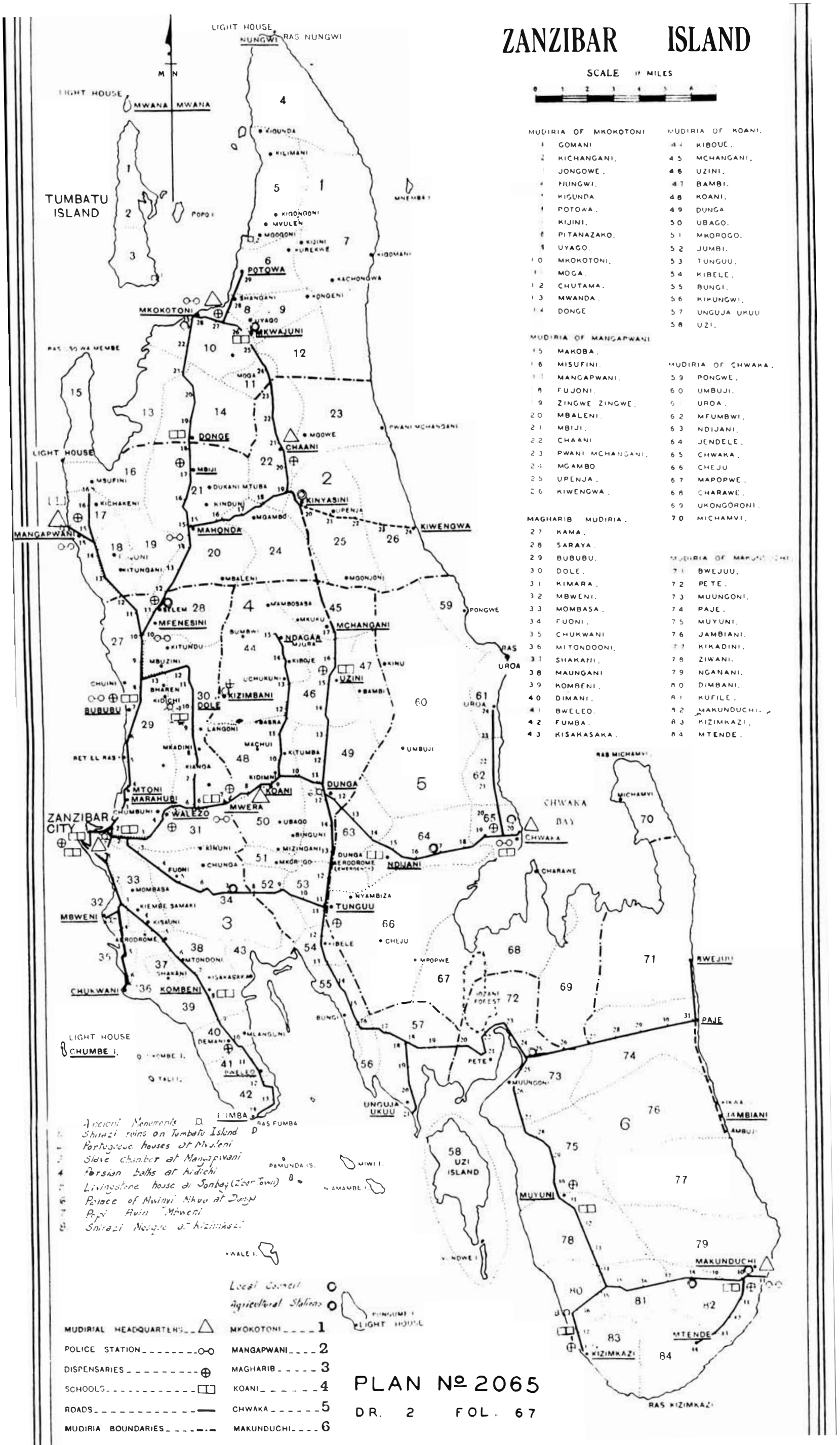




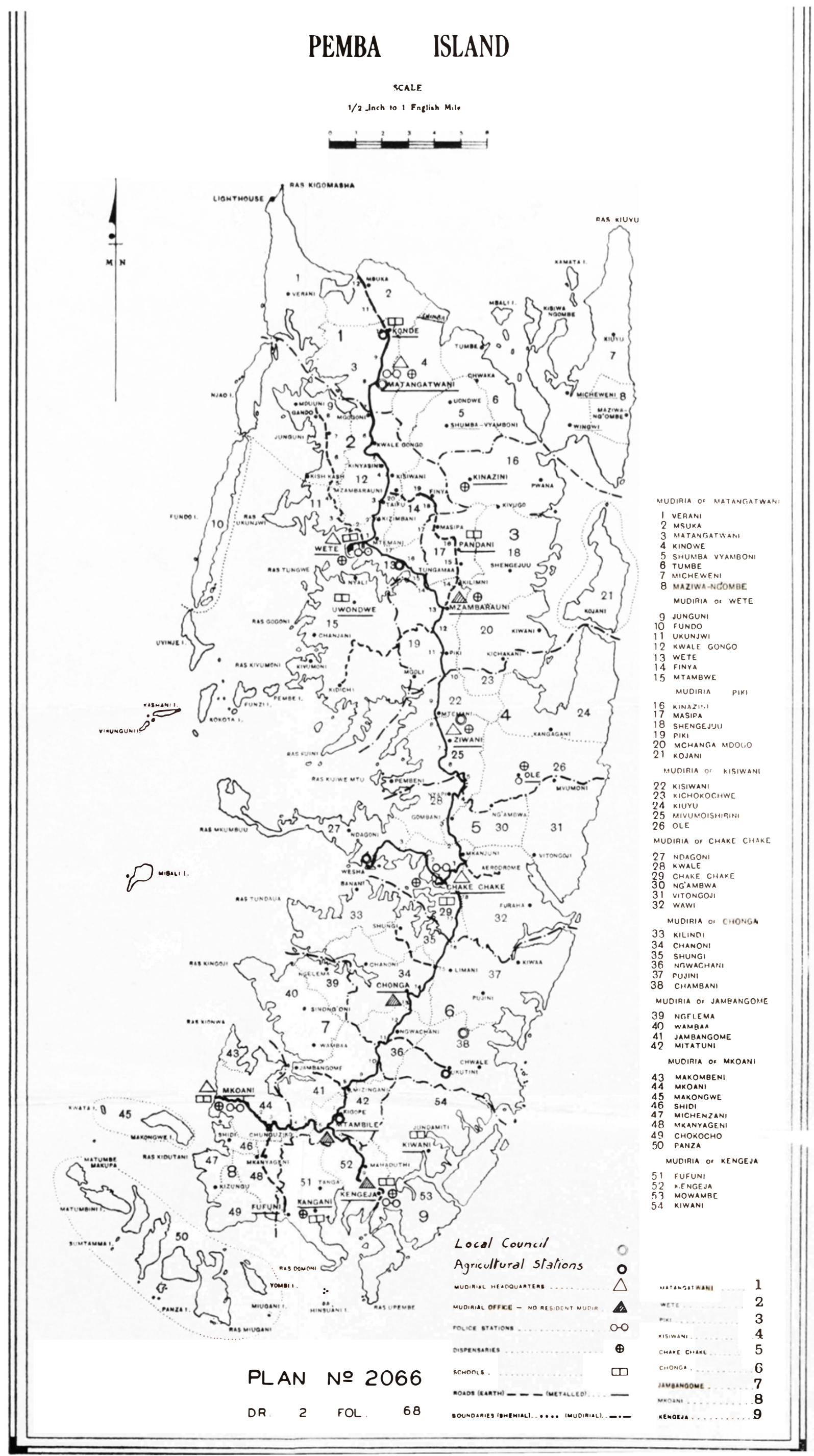

